\title{
HUBUNGAN ANTARA POLA ASUH ORANG TUA DENGAN KEMAMPUAN ADAPTASI PADA ANAK USIA PRASEKOLAH DI TK PANTI PURUHITA KRAPYAK KOTA SEMARANG
}

\section{Relationship Between Parents' Patterns With Adaptation Skills in Children Of President School In Panti Puruhita Krapyak Tk Semarang City}

\author{
Wahyuningsih \\ Akper Widya Husada Widya Semarang \\ Jl. Subali Raya No.12 Krapyak Semarang Telp 024-7612988-7612944 \\ Wahyu198223@yahoo.com
}

\begin{abstract}
ABSTRAK
Dari hasil studi pendahuluan dengan 8 anak, anak yang mendapat pola asuh demokratis 5, otoriter 2, permisif 1.Penyesuaian diri pada anak TK diawali adanya kecemasan dari anak saat berpisah dengan orang tua, menangis dan penarikan pada awal masuk sekolah.Hal ini berkaitan dengan peran orang tua dalam mempersiapkan anak masuk sekolah. Tujuan dari penelitian ini adalah untuk mengetahui hubungan antara pola asuh orang tua dengan kemampuan adaptasi pada anak usia prasekolah di TK Panti Puruhita Semarang. Metode : Metode yang digunakan dalam penelitian ini yaitu korelasi dengan desain penelitian cross sectional. Subyek penelitian sebanyak 72 responden di TK Panti Puruhita Semarang dengan menggunakan total sampling. Pengumpulan data menggunakan kuesioner. Hasil : Hasil penelitian menunjukkan bahwa orang tua dengan pola asuh demokratis sebanyak 40responden $(55,6 \%)$, otoriter 27 responden $(37,5 \%)$ dan permisif sebanyak 5 responden $(6,9 \%)$. Hasil korelasi rank spearman menunjukkan p value $=0,001$ atau $<0,05$. Kesimpulan : Dapat disimpulkan bahwa terdapat hubungan antara pola asuh orang tua dengan kemampuan adaptasi pada anak usia prasekolah di TK Panti Puruhita Krapyak Kota Semarang.
\end{abstract}

Kata Kunci :Pola Asuh Orang Tua, Kemampuan adaptasi, Usia prasekolah.

\section{ABSTRACT}

Background :Based on the analysis introduction with 6 children, children who have a democratic parenting is 3 , authoritarian is 2, and permissive is 1. Adjustment of kindergarten children begins the anxiety of children when separated from parents, crying and withdrawal at the beginning of school entry. This is related to the role of parents in preparing children for school. This study aimed to determine the relationship of parenting parents with adaptation skills in preschoolers at Panti Puruhita Semarang Kindergarten. Method: The method used in this research is correlation with cross sectional study design. Research subjects were 72 parents from Kindergarten Panti Puruhita Semarang using total sampling. Data collection using questionnaires. Result : Based on the analysis of data obtained from 72 respondents study, older people with democratic parenting were $40(55.6 \%)$, authoritarian $27(37.5 \%)$, permissive $5(6.9 \%)$. The result of spearman rank correlation showed $p$ value $=0,001$ or $<0,05$. Conclusion : It can be concluded that There is a correlation patterns of parenting with adaptation skills in preschool children in kindergarten Panti Puruhita Semarang. So it is suggested for parents especially mothers to pay attention and prepare children to enter school in adaptation in school environment either with teacher, friend and environment around school.

Keywords: Patterns of parenting, adaptation ability, preschool age.

\section{PENDAHULUAN}

Anak merupakan individu yang masih bergantung pada lingkungan untuk memenuhi kebutuhan individualnya. Lingkungan yang mendukung tersebut salah satunya adalah keluarga,yaitu orang tua dengan melalui pendekatan Family
Centered Care (Hanson1997, dalam Dunstdan Trivette, 2009). Menurut Hidayat (2005) anak sangat membutuhkan dukungan yang kuat dari keluarga, hal ini dapat terlihat melalui pola asuh. Pola asuh menurut Stewart dan Koch(2010) terdiri dari tiga pola asuh orang tua yaitu pola 
asuh otoriter, pola asuh demokratis, dan pola asuh permisif. Pola asuh otoriter, mempunyai ciri antara lain kaku,tegas,suka menghukum, kurang ada kasih sayang serta simpatik. Pola asuh demokratis, dapat menumbuhkan keyakinan dan kepercayaan diri maupun mendorong tindakan-tindakan mandiri, berakibat munculnya tingkah laku mandiri yang bertanggung jawab. Pola asuh permisif,cenderung selalu memberikan kebebasan pada anak tanpa memberikan kontrol sama sekali.

Pola pengasuhan otoriter menyebabkan anak patuh dan pintar, tapi mereka kurang dalam kebahagiaan, kompetensi sosial dan harga diri. Pola pengasuhan demokratis cenderung menghasilkan anak yang bahagia, kompeten dan sukses. Pola pengasuhan permisif menyebabkan anak kurang bahagia dan disiplin. Anak lebih mungkin mengalami masalah dengan aturan dan cenderung berkinerja buruk di sekolah (Baumrind, 2013).

Orang tua mempunyai peran besar dalam pembentukan perkembangan social - emosional anak (Boyd et al, 2005). Orang tua dapat secara langsung memberi contoh kepada anak - anak mereka tentang bagaimana mengelola emosi dengan baik pada kondisi tertentu, sehingga akhirnya dapat meningkatkan kemampuan sosialisasi (Miller, 2011). Dengan memiliki pengelolaan emosi yang baik, dapat membantu anak untuk beradaptasi dengan lingkungan sekolah (Coplan, Arbeu, \& Armer, 2008).

Penelitian juga dilakukan oleh Kramer, Caldarella, Christense, dan Shatzer (2010) membuktikan bahwa terjadi peningkatan dalam perilaku anak setelah memperoleh pembelajaran sosialemosional. Permasalahan sosial - emosi biasanya terjadi pada anak yang pemalu yang bisa menyebabkan anak mengalami kesulitan untuk menyesuaikan diri (Coplan, Arbeau, \& Armer, 2008). Masalah yang muncul pada awal karir sekolah anak sering menjadi masalah yang menetap karena faktor sosial - psikologis dan memperburuk keadaan saat kesulitan muncul dan menghambat perkembangan selanjutnya (Supobro,2008). Penyesuaian diri dan kemandirian sangat berperan penting terhadap perkembangan emosi peserta didik, dimana untuk membentuk pribadi yang wibawa dan cakap dilingkungannya (Jaya, 2012).

Sekitar 9,5\% - 14,2\% anak prasekolah memiliki masalah sosial yang berdampak negatif terhadap perkembangan dan kesiapan sekolahnya (Braunner \& Stephens, 2006). Penelitian menunjukan 8 - $9 \%$ anak prasekolah mengalami masalah psikososial khususnya masalah sosial emosional seperti kecemasan atau perilaku agresif (Velderman et al, 2010).

Menurut Wong (2004), pertumbuhan dan perkembangan selama tahun prasekolah antara lain fisik,motorik kasar,motorik halus,bahasa, sosialisasi, kognitif dan hubungan keluarga. Kemampuan mengekspresikan diri pada anak usia pra sekolah, dimulai dengan mengajari anak mengungkapkan emosinya. Ciri Emosional Pada Anak Prasekolah yaitu, Anak TK cenderung mengekspresikan emosinya dengan bebas dan terbuka. Sikap marah sering diperlihatkan oleh anak pada usia tersebut,iri hati pada anak prasekolah sering terjadi,mereka seringkali memperebutkan perhatian guru(Ananda, 2010).

Peran perawat anak antara lain, membina hubungan terapeutik, advokasi atau caring keluarga, pencegahan penyakit atau promosi kesehatan, penyuluhan kesehatan, dukungan atau konseling, peran restoratif, koordinasi atau kolaborasi,pengambilan keputusan etis,sebagai riset (Wong,et al, 2009).

Bardasarkan studi pendahuluan yang telah dilakukan di TK Panti Puruhita Krapyak Semarang, didapatkan tiga orang tua menggunakan pola asuh demokratis, dimana orang tua membebaskan anak 
untuk bermain dan ada waktunya untuk belajar. Anak terlihat mampu mengontrol emosi, mampu bersosialisasi dengan teman-teman, mampu memperhatikan ketika diajarkan sesuatu dan mengulang kembali serta mampu mengungkapkan perasaan.

Selain itu ditemukan puladua orang tua menggunakan pola asuh otoriter, dimana orang tua membentuk anaknya sesuai keinginan mereka. Hasil pola asuh tersebut, anak terlihat kurang mampu mengontrol emosinya, sulit untuk bersosialisasi denganteman-teman, kurang memperhatikan ketika diajarkan sesuatu dan tidak bisa mengulang kembali,dan sulit untuk mengungkapkan perasaan. Pada satu orang tua yang menggunakan pola asuh permisif, dimana orang tua memanjakan anak secara berlebihan, misal semua keinginan anak dipenuhi tanpa mempertimbangkan sebab dan akibat. Anak dengan pola asuh permisif terlihat manja, kurang mampu bertanggung jawab, terlalu tergantung kepada orang tua.

\section{Metode Penelitian}

Penelitian ini menggunakan desain penelitian desain korelasi dengan pendekatan cross sectional, yaitu suatu penelitian yang pengambilan data terhadap variabel independen dan dependen dilakukan pada satu waktu. Sampel dalam penelitian ini adalah total sampling sejumlah 72 orangtua dan murid pada bulan febuari 2018. Instrumen penelitian yang digunakan untuk mengetahui hubungan antara pola asuh orang tua dan kemampuan adaptasi anak usia prasekolah adalah kuesioner. Data dianalisis dengan menggunakan analisis Spearmanrank dengan bantuan SPSS 16 for Windows. Penelitian ini dilaksanakan pada bulan febuari selama 3 hari di TK Panti Puruhita Semarang yang terletak di jalan Kurantil I Perumnas Krapyak Kota Semarang.

Hasil

Hasil data khusus berisi karakteristik responden yang meliputi frekuensi pola asuh orang tua, kemampuan adaptasi anak dan hubungan pola asuh orang tua dengan kemampuan adaptasi anak.

1. Karakteritik responden berdasarkan pola asuh orang tuadi TK Panti Puruhita krapyak kota Semarang

\section{Tabel 1 Distribusi Frekuensi Pola AsuhOrang Tua di TK Panti Puruhita Krapyak Kota Semarang $(n=72)$}

\begin{tabular}{llll}
\hline Pola Asuh Orang Tua & & Frekuensi & Presentasi (\%) \\
\hline Demokratis & 40 & 55,6 & 37,5 \\
Otoriter & 27 & 6,9 & \\
Permisif & 5 & $\mathbf{1 0 0}$ & \\
\hline Total & $\mathbf{7 2}$ & \\
\hline
\end{tabular}

Berdasarkan Tabel 1 menunjukkan bahwa dari 72 responden orang tua yang memiliki pola asuh demokratis yaitu sebanyak 40 orang, $(55,6 \%)$, sedangkan pola asuh otoriter sebanyak 27orang $(37,5 \%)$, dan pola asuh permisif sebanyak 5 orang $(6,9 \%)$. 
2. Kemampuan Adaptasi pada anak usia prasekolah di TK Panti Puruhita krapyak kota Semarang

$\begin{aligned} & \text { Tabel } 2 \text { Distribusi Frekuensi Responden Berdasarkan Kemampuan Adaptasi Pada } \\
& \text { Anak Usia Prasekolah Di TK Panti Puruhita Krapyak Kota Semarang } \\
& \text { n=72 }\end{aligned}$
\begin{tabular}{ccc}
\hline Kemampuan adaptasi pada anak usia prasekolah & Frekuensi & Presentasi (\%) \\
\hline Buruk & 0 & 0 \\
Cukup & 12 & 16,7 \\
Baik & 60 & 83,3 \\
\hline Total & $\mathbf{7 2}$ & $\mathbf{1 0 0}$ \\
\hline
\end{tabular}

Berdasarkan Tabel 4.2 menunjukan bahwa kemampuan adaptasi pada anak usia prasekolah kategori baik sebanyak 60 $(83,3 \%)$ responden, kategori cukup sebanyak 12 responden $(16,7 \%)$ dan kategori buruk sebanyak 0 responden $(0 \%)$ dari 72 responden.

3. Hubungan Pola Asuh Orang Tua Dengan Kemampuan Adaptasi Anak Prasekolah Di TK Panti Puruhita Krapyak Kota Semarang

Tabel 3 Hubungan Pola Asuh Orang Tua Dengan kemampuan adaptasi Anak Prasekolah Di TKPanti Puruhita Krapyak Kota Semarang $(\mathbf{n}=72)$

\begin{tabular}{|c|c|c|c|c|c|c|c|}
\hline \multirow{4}{*}{ Pola Asuh Orang Tua } & \multicolumn{6}{|c|}{ Kemampuan Adaptasi Anak Usia } & \multirow{4}{*}{$P$ value } \\
\hline & \multirow{2}{*}{\multicolumn{2}{|c|}{ Baik }} & lah & & \multirow{2}{*}{\multicolumn{2}{|c|}{ Total }} & \\
\hline & & & \multicolumn{2}{|c|}{ Cukup } & & & \\
\hline & $\mathrm{N}$ & $\%$ & $\mathrm{~N}$ & $\%$ & $\mathrm{~N}$ & $\%$ & \\
\hline Demokratis & 30 & 41,7 & 10 & 13,9 & 40 & 55,6 & \\
\hline Otoriter & 20 & 27,8 & 7 & 9,7 & 27 & 37,5 & م 01 \\
\hline Permisif & 4 & 5,5 & 1 & 1,4 & 5 & 6,9 & 0,001 \\
\hline Total & 60 & 83,3 & 12 & 16,7 & 72 & 100 & \\
\hline
\end{tabular}

Berdasarkan Tabel 3 menunjukkan bahwa dari 72 responden, anak yang mendapat pola asuh orang tua demokratis memiliki kemampuan adaptasi baik sebanyak $\quad 30$ anak $(41,7 \%)$, dan kemampuan adaptasi cukup sebanyak 10 anak $(13,9 \%)$. Anak yang mendapat pola asuh orang tua otoriter memiliki kemampuan adaptasi baik sebanyak 20 anak $(27,8 \%)$, dan anak yang kemampuan adaptasi cukup sebanyak 7anak $(9,7 \%)$. Anak yang mendapat pola asuh permisif kemampuan adaptasi baik sebanyak 4 anak $(5,5 \%)$, dan kemampuan adaptasi cukup sebanyak lanak $(1,4 \%)$.

Dari hasil analisis diatas dapat disimpulkan bahwa sebagian besar anak prasekolah yang mendapat pola asuh orang tua demokratis memiliki kemampuan adaptasi baik,yaitu sebanyak 30 anak $(41,7 \%)$. Berdasarkan hasil ujistatistik dengan rank spearman diperoleh nilai $p$ value sebesar $0,001(\leq 0,05)$. Karena $p$ value $(0,001) \leq 0,05$ maka dapat disimpulkan Ho ditolak dan Ha diterima, yang berarti Ada Hubungan Pola Asuh Orang Tua Dengan Kemampuan Adaptasi Anak Di TK Panti Puruhita Krapyak Kota Semarang.

\section{PEMBAHASAN}

Berdasarkan hasil penelitian menunjukkan bahwa dari 72 responden diketahui bahwa sebagian besar orang tua memiliki pola asuh demokratis sebanyak 40 orang $(55,6 \%)$. Karena orang tua dengan pola asuh demokratis memandang sama kewajiban dan hak antara orang tua 
dan anak. Secara bertahap orang tua memberikan tanggung jawab bagi anakanaknya terhadap segala sesuatu yang diperbuatnya sampai mereka menjadi dewasa. Orang tua selalu berdialog dengan anak-anaknya,saling memberi dan menerima, selalu mendengarkan keluhankeluhan dan pendapat anak-anaknya. Orang tua selalu memberikan alasannya dalam setiap tindakan kepada anak, mendorong anak Saling membantu dan bertindak secara obyektif, tegas tetapi hangat dan penuh pengertian.

Menurut Baumrind (2013) dampak positif yang terjadi jika orang tua memiliki pola asuh demokratis adalah orang tua dapat menumbuhkan keyakinan dan kepercayaan diri serta berakibat munculnya tingkah laku mandiri yang bertanggung jawab. Selain itu, pada pola pengasuhan yang demokratis cenderung menghasilkan anak yang bahagia, kompeten dan sukses pada karirnya dimasa mendatang.

Pola asuh otoriter menurut Stewart dan Koch (2010), orang tua tidak memberikan hak anaknya untuk mengemukakan pendapat serta mengutarakan perasaanperasaannya, sehingga pola asuh otoriter berpeluang untuk memunculkan perilaku agresif. Anak patuh terhadap orang tua hanya ingin menyenangkan hati orang tua saja. Sedangkan menurut Baumrind (2013), dampak yang terjadi jika orang tua memiliki pola asuh otoriter adalah menyebabkan anak patuh dan pintar, tapi mereka kurang dalam kebahagiaan, kompetensi sosial dan harga diri. Dalam penelitian ini orang tua yang memiliki pola asuh otoriter sebanyak 27 orang $(37,5 \%)$.

Menurut Stewart dan Koch (2010), pola asuh permisif cenderung selalu memberikan kebebasan pada anak tanpa memberikan kontrol sama sekali.Orang tua kurang tegas dalam menerapkan peraturanperaturan yang ada.Sedangkan menurut Baumrind (2013), dampak dari pola asuh permisif adalah anak kurang bahagia, kompeten dan sukses. Dalam penelitian ini orang tua yang memiliki pola asuh permisif sebanyak 5 orang $(6,9 \%)$.

Ketiga pola asuhtersebut sebenarnya memiliki kelebihan masing- masing, kelebihan dari ketiga pola asuh antara lain, pola asuh otoriter akan membuat anak lebih mengetahui aturan. Karena orang tua banyak mengatur dan anak tidak ada pilihan lain. Kalau permisif, anak cenderung lebih kreatif karena terkadang bisa memutuskan sendiri pilihannya. Sedangkan demokratis anak lebih bertanggung jawabakan pilihannya dan dapat mengungkapkan pendapat dengan logis. Pola asuh demokratis, lebih banyak memberikan kelebihan. Karena mengajarkan anak lebih percaya diri,kreatif dan menjalin komunikasi dua arah (Cahyaningrum, 2013).

Pola asuh orang tua juga dapat membentuk karakteristik anak- anaknya, antara lain pola asuh demokratis akan menghasikan karakteristik anak-anak yang mandiri, dapat mengontrol diri, mempunyai hubungan baik dengan teman, mampu menghadapi stress, mempunyai minat terhadap hal-hal baru dan koperatif terhadap orang-orang lain. Pola asuh otoriter akan menghasilkan karakteristik anak yang penakut, pendiam, tertutup, tidak berinisiatif, gemar menentang, suka melanggar norma, berkepribadian lemah, cemas dan menarik diri. Sedangkan pola asuh permisif akan menghasilkan karakteristik anak-anak yang impulsive, agresif, tidak patuh, manja, kurang mandiri, mau menang sendiri,kurang percaya diri,dan kurang matang secara sosial (Taufik, 2006).

Hasil penelitian yang dilakukan oleh peneliti didapatkan bahwa dari 72 reponden, yang memiliki kemampuan adaptasi di TK Panti Puruhita Semarang seebagian besar memiliki kemampuan adaptasi baik sebesar 83,3 \%. Dari hasil diatas dapat kita lihat bahwa ada beberapa anak di TK Panti Puruhita Semarang dalam kategori cukup yang mempunyai kemampuan adaptasi pada lingkungan, 
baik lingkungan sekolah maupun masyarakat. Pada lingkungan sekolah misalnya masih ada anak yang kurang aktif pada waktu pembelajaran, ada anak yang menghindar ketika dipanggil guru, ada anak yang masih bermain pada waktu pembelajaran dan beberapa anak yang pada waktu istirahat langsung berlari ke orang tua yang sedang menunggu diluar kelas.

Berdasarkan hasil penelitian diketahui bahwa dari 72 responden yang diteliti, 30 anak $(41,7 \%)$ memiliki kemampuan adaptasi baik dengan pola asuh demokratis. Hal ini bisa menjadi panduan untuk para orang tua, bahwa pola asuh yang paling baik untuk diterapkan kepada anak adalah pola asuh demokratis.

Hasil uji rank spearman menunjukkan bahwa ada hubungan pola asuh orang tua dengan kemampuan adaptasi anak prasekolah di TK Panti Puruhita krapyak Kota Semarang, $p$ value $(0,001<0,05)$, yang berarti $\mathrm{H}_{0}$ ditolak dan $\mathrm{Ha}$ diterima, maka ada hubungan antara pola asuh orang tua dengan kemampuan adaptasi anak prasekolah di TK Panti Puruhita krapyak Kota Semarang.

\section{KESIMPULAN}

Hasil penelitian menunjukkan bahwa ada hubungan pola asuh orang tua dengan kemampuan adaptasi pada anak usia prasekolah. pengalaman yang kurang dan stressor baru dalam menghadapai dunia sekolah akan sangat menentukan persepsi anak yang diaplikasikan dalam bentuk perilaku menolak atau enggan bersekolah.

Meskipun tidak satu pun pola pendidikan anak yang dapat menjamin penyesuaian diri yang baik atau penyesuaian yang buruk, baik pribadi maupun sosial, ada bukti yang menunjukkan bahwa anak yang dibesarkan dalam suasana rumah yang demokratis umumnya mempunyai penyesuaian diri yang lebih baik dengan orang-orang di luar rumah daripada anak-anak dari suasana rumah yang lembut atau otoriter (Hurlock,
2013).

SARAN

Penelitian ini diharapkan akan menambah pengetahuan dan informasi bagi orang tua khususnya ibu dalam mendidik anaknya agar lebih mudah dalam beradaptasi di lingkungan sekolah baik dengan guru, teman maupun lingkungan sekitar sekolah. Perlu adanya penelitian lanjutan tentang eksplorasi faktor-faktor yang mempengaruhi kemampuan adaptasi pada anak pra sekolah selain pola asuh orang tua.

\section{DAFTAR PUSTAKA}

Ananda, K.S.2014. Maternal Hemoglobin and Birth Weight : systematic Review and meta Analysis. International Journal of Medical Science and Public Health 245 vol 4

Baumrind, D.2013.Current pattern of parental Authority, Development psychology.Monograph 4. No 1 Bench Mark Publisher.

Boyd. J., Baarnett,W.S., Bondrova, E., Leong, D. J. \& Gamby, D.. 2005. Prommoting Children's Social and emotional development through preschool education dalam National Institute for Early Education Research.

Braunner, C. B.,\& Stephens, C. B.2006. Estimating the Pravalence of early Childhood serious emotional / behavioral disorder :

Challanges and recommendations. Public Health Reports, 303-310.

Cahyaningrum, M. 2013. Hubungan Antara Pengetahuan Ibu Tentang Stimulasi Dengan Tingkat Perkembangan Pada Anak Usia 3-5 Tahun Dikelurahan Kranggan Temanggung. Naskah Publikasi, Program Studi Ilmu Keperawatan STIK Aisyiyah, Yogyakarta.

Coplan, R.J., Arbeu, K.A.,\& Armer, M. 2008. Don't fret, be suppprtive! Maternal characteristicslinking child shyness to psychosocial and school adjustment in kindergarten. Journal of bnormal child psychology, 36, 359-371

Dunts, C.J., Trivette, C.M.T.2009. Meta-Analytic Structural Equation Modelling of Family Centered Care on Parent and Child Psycological Health. International Journal of Pediatrics.1-9.

Hidayat, A. Aziz Alimul. 2005. Pengantar Ilmu Keperawatan Anak, Edisi I. Salemba Medika :Jakarta 
Hurlock, E. 2013. Psikologi Perkembangan (Alih Bahasa. Dra. Istiwidayanti dan Drs. Soedjarwo). Jakarta. Erlangga.

Jaya, Adisan. 2012. Peranan Penyesuaian Diri Dan Kemandirian Terhadap Perkembangan Emosi Peserta Didik.

http://adisastrajaya.blogspot.com/2012/06/ar tikel-peranan-penyesuaian-diri-dan.html. 9 mei 2013

Krammer,T.J, Caldarella, P., Christensen, L.,\& Shatzer, R.H.2010. Social And Emotional Learning In The Kindergarten Classroom : Evaluation Of The Story Start Curriculum. Early Childhood Education Journal, 37,303-309.doi : 1007/s10643-009-0354-8

Miller, S.R. Tserakhava, V, Miller, C.J. 2011. "My Child Is Shy And Has No Friends : What Does Parenting Have To Do About It? “" Journal Of Youth Adolescense, 40, 442-452.
Stewart \& Koch. 2010. Children Development Throught Adolescence. Canada : John Willey and Sons.Inc

Suprobo, Noviana. 2008. Penyesuaian Diri Anak TK. http:// novianasuprobo.wordpress.com/2008/06/15/ penyesuaian-diri-anak-tk. Tanggal 10 September 2012.

Taufik, Rina. 2006. Karakteristik Anak Pra Sekolah. Devisi Kewanitaan IMB

Velderman, M.K.,Crone, M.R., Wiefferink, C.H., \& Reijneveld, S.A.2010. Identification Management Of Psichosocial Problems Amog Toddlers By Preventive Child Health Care Professionals. The European Journal Of Public Health, 20(3), 332-338.

Wong, Donna L. 2004. Pedoman Klinis Keperawatan Pediatrik Edisi 4. Jakarta: EGC

Wong, Donna L. 2009. Buku Ajar Keperawatan Pediatrik Volume 1. Jakarta: EGC 